\title{
The Relation Between Readiness for Self-learning and Learning Style Preferences Among Nursing Students
}

\author{
Ahmed Mohamed Megahed ${ }^{1}$,Samia Mohamed Abdalla Adam² , Marwa Mohamed \\ Abdel Aleem ${ }^{3}$ \\ B.Sc. nursing, port said university ${ }^{1}$, professor of nursing administration faculty of nursing \\ -Ain shams university ${ }^{2}$, lecture of nursing administration faculty of nursing- port said \\ university
}

\begin{abstract}
Background: Self-directed learning is a needful skill for students t0 remain lifel0ng learners. As they gain knowledge and succeed academically in their chosen disciplines. Therefore, awareness of learning styles should be promoted. Aim: the study aimed to study the relation between readiness f0r self-learning and learning style preferences am0ng nursing students. Subjects and method: the study was conducted at faculty of nursing/Port-Said University using a descriptive correlational research design; 174 students from the four undergraduate academic years were enclosed in the study. Two tools were used namely; Self-Directed Learning Readiness Scale (SDLRS) and Learning Styles Self-Assessment Questionnaire. Results: $27 \%$ of studied nursing students had average score for self-directed learning readiness while $41.4 \%$ were blew average and $31.6 \%$ were above average. Moreover, the most preferred learning style among student was kinesthetic (44.8\%), then visual (28.2\%) and auditory (27\%). Conclusion: The study findings concluded that there was no statistically significant relation between selfdirected learning readiness and learning style. Recommendations: Students needs to be supported to move from conventional education to more active and autonomous education, depend on self-directed learning.
\end{abstract}

Key words: nursing students, learning style, self-learning 


\section{INTRODUCTION}

In a rapidly changing and unstable world, many countries strive to remain competitive by updating the national education strategies (Kan'an and Osman,2015). As well, given the continuous advances in nursing sciences, nurses need to develop the skills that will enable them to be lifelong learners. Self-directed learning (SDL) is considered by many researchers as the most appropriate methodology to allow nurse-practitioner to stay up-to-date and knowledgeable (Murad, et al ,2010)

Accordingly, Self-learning is a needful skill for students to remain lifelong learners as it considered an educational tool increasingly used in adult education within higher education institutions (Örs, 2018). It leads to the development of skills to meet the challenges associated with modern global systems (Siminică and Traistaru, 2013).

In addition, self-learning skills (SDL) enable students to identify and manage their own learning needs rather than depending on their teachers. Hence, schools' learning activities must enc0urage the development of SDL skills so that it may help students to succeed in their present and future learning (Kan'an and Osman, 2015)

Readiness for self-directed learning is defined as the degree to which an individual has the attitudes, talents, and personality traits necessary for self-directed learning (Prabjanee and Inthachot, 2013).

SDL readiness naturally exists along a continuum ranging from high levels to moderate and that individual's level of readiness can be demonstrated through individual personal characteristics such attitude, values, and abilities; and It is appropriate to establish SDL readiness because appropriate intervention can enhance learners' readiness for selfdirected learning (Guglielmino, 2013).

Fein (2014) revealed that students who are motivated for learning their performance will be better in future and they will become independent and have good readiness for selfdirected learner. Students will work independently. In nursing profession students enter with professional training, learn from mistakes, continually up to date their knowledge and skills through self-reliant abilities (Fein, 2014).Current patterns in training and education highlighted that undergraduates get new skills and practices so, they could become lifelong learner and have better readiness of self-learning (El-Gilany and Abusaad, 2013). 
Supporting self-directing learning, nurse-educators should facilitate student's development and socialization by determining individual's learning style preferences and needs. Learning style can be defined as the way people absorb process and retain information (Francis, Mahlomaholo, and Nkoane, 2010). Moreover, Moran (1991) defined it as individual differences in thinking, differences in interests, differences in literature, and differences in cognitive backgrounds addressed by people's behavior.

As stated by Gerding (2007), there are many ways to categorize learning approaches. Many common learning styles theories are based on sensory preference with broad categories that include visual, auditory, kinesthetic. Visual style: in this style learners are distinguished by possessing two sub-channels Linguistic and Spatial. Auditory style: in this style learner learns easily through verbal lessons and anything that allows them to talk out what they are learning. Kinesthetic style: This group is mainly marked by two sub-channels: Kinesthetic having to do with movement and Tactile pertaining to the sense of touch (Bill and Rosie, 2019).

SDL readiness and learning styles have been explored in numerous studies due to the need to understand the components and relationships among their constructs, which in turn, may enhance students' learning outcomes (Alharbi, 2018).

\section{Significance of the Study}

As self-directed learning is vital in today's world, educational institutions are expected to consider the individual differences of learners in order to encourage them to direct their own learning. A literature review strongly indicates how important understanding of learning styles and the role of learning styles in teaching / learning process are important for effective teaching. When students understand how they learn and their preferred ways of learning, the likelihood of learning increases.

\section{AIM OF STUDY :}

Study the relation between readiness for self-learning and learning style preferences among nursing students at Port-Said University 


\section{Objectives:}

\section{The objectives of this study are to:}

- Assess the nursing student's readiness for self-learning at Port-Said University

- Identify the nursing students' learning style preferences at Port-Said University

- Find-out the relation between nursing students' readiness for self-learning and their learning style preferences at Port-Said University

\section{Research Question:}

- Are the students ready for self-directed learning at Port-Said Faculty of Nursing?

-What is the most learning style preference of the students at Port-Said Faculty of Nursing?

- Is there a relati0nship between nursing students' readiness f0r self-learning and their learning style preferences at Port-Said University?

\section{SUBJECTS AND METHOD:}

Research design: this descriptive correlational study

Setting: the study was conducted in the Faculty of Nursing, Port- Said University, that adopting innovative approaches in education, such as Problem Based Learning (PBL), Community Based Learning (CBL), and Self-Learning (SL).

Subjects: the study was carried out on 174 nursing students chosen by Stratified Random Sample from entire population (316): 56 from first year, 75 from second year, 82 from third year and 103 from forth year

\section{Tools of data collection:}

Data collected by using two tools; Self-Directed Learning Readiness Scale and VAK Learning Styles Self-Assessment Questionnaire.

\section{TOOL I:}

This tool consists of two parts

Part 1: personal and academic characteristics Data Sheet

This part aimed to collect data regarding student' age, academic year, gender and training programs

\section{Part 2: Self-Directed Learning Readiness Scale}


Self-Directed Learning Readiness Scale developed by Guglielmino (1977). It consists of 58(MCQ) items, these items rated on 5-point Likert-type scale. The 58 items divided to four dimension Self confidence in abilities and skills for learning (18), Learning is a tool for life (14), and Responsibility for own learning (14) and Curiosity (12), this dimensions were categorized by Hoban, Lawson, Mazmanian, Best, and Seibel (2005) .

Scoring system of Self-Directed Learning Readiness Scale:

\begin{tabular}{|l|l|l|}
\hline $\begin{array}{l}\text { SDLR(Self-Directed } \\
\text { Learning Readiness } \\
\text { Scale) score }\end{array}$ & $\begin{array}{l}\text { (Self-Directed Learning Readiness } \\
\text { Scale) mean percent }\end{array}$ & $\begin{array}{l}\text { Readiness for Self- } \\
\text { Directed Learning }\end{array}$ \\
\hline $\mathbf{5 8 - 2 0 1}$ & Less than 69 & Below average \\
\hline $202-226$ & From 70 to 78 & Average \\
\hline $227-290$ & More than 78 & Above average \\
\hline
\end{tabular}

TOOLII : VAK Learning Styles Self-Assessment Questionnaire

It was developed by Chislett and Chapman (2005), consists of 30 (MCQ) questions every question has 3answer (A's, B's, C's) .

Scoring system of VAK Learning Styles

If student choose mostly $\mathrm{A}$, have a visual learning style.

If student choose B mostly, have an auditory learning style.

If student choose $\mathrm{C}$ mostly, have a kinesthetic learning style.

Face Validity of a Structured questionnaire sheet tool: -

It was ascertained by five experts in nursing administration. Necessary modifications were done according to the experts' opinions. Translation of some items has been modified.

\section{Reliability of a Structured questionnaire sheet tool:-}

It was held on $10 \%$ of total number of studied participants in Faculty of Nursing Port-Said University. Cronbach's alpha coefficient was used to assess the internal consistency of data collection for Adult Learning Questionnaire was 0.75 while for VAK Learning Styles Self-Assessment Questionnaire was 0.78. 


\section{Pilot Study:}

A pilot study was carried out on $10 \%$ of the included total sample of student nurses from Port Said University. The purpose of the pilot study was to test applicability, clarity, relevance, feasibility of the research tool. Pilot study conducted before starting of data collection. It took about one month from December 2018 to January 2019. Based on the findings of pilot study, no modifications carried out on the tools.

\section{Field of work}

Upon fulfillment of all administrative arrangements, data collection phase was initialized by meeting with students in the beginning, ending or in the break of PBL sessions for four days per week, according to their academic time schedule. The researcher introduced himself to students; and distributed the tools and asked them to fill it after explaining the aims of the study and its implication on the spot in the presence of the researcher to ensure the objectivity of the responses. The researcher collected data by himself with assistance from sessions' tutors. The filled forms were then collected and revised for completeness. The time needed to fill questionnaires was 15-20 minute. The study was conducted during the academic year 2018 - 2019 from beginning of December 2018 to the end of March 2019 after obtaining the official permission to conduct the study.

Administrative and ethical consideration: A written permission to carry out the study was obtained from Faculty Dean, with coordination of Vice-Dean of Education and student's affair and academic years' coordinators to facilitate the process of data collection. The purpose of the study was explained to the students before taking their informed consent and informed of their right to refuse to participate in the study. Also, they were secured that any information obtained would be confidential and used only for purpose of the study.

\section{Statistical analysis:}

The collected data was organized, revised, stored, tabulated and analyzed using the number and percentage distribution. Statistical analysis was done by computer using Statistical Package of Social Science program (SPSS). Proper statistical tests were used to determine whether there was a significant statistical difference between the variables of the study. Data were presented in tables and figures. Percentage, Pearson correlation (r), chi-square (x2), proportion probability of error (p-value) were used. 


\section{RESULTS:}

Table (1): displays that $82.2 \%$ of studied nursing students had 20 years old or more, $67.8 \%$ were female, $32.2 \%$ were in the fourth academic year and $87.4 \%$ of studied nursing students had attended training program.

As shown in Table (2) more than one quarter (27\%) of studied nursing students had an average score for self-directed learning readiness while $41.4 \%$ were blew average and $31.6 \%$ were above average.

Table (3): demonstrates that the higher dimension among SDL readiness scale dimensions is self confidence in abilities and skills for learning (68.8 \pm 13.4$)$, followed by responsibility for own learning $(56.7 \pm 10.9)$, learning is a tool for life $(50.2 \pm 9.8)$, then curiosity $(41.8 \pm 8.1)$

As for the nursing students' preferred learning style Table (4) illustrated that the most preferred learning style was kinesthetic (44.8\%), then visual (28.2\%) and auditory (27\%)

Concerning the relation between SDLR and preferred learning style Table (5) demonstrates that there is no significant relation between SDLR and preferred learning style in the four academic years $(\mathrm{p}=0.492,0.142,0.129 \& 0.139)$. 
Table (1): Frequency distribution of personal and academic characteristics of studied nursing students $(\mathrm{n}=174)$

\begin{tabular}{|c|c|c|}
\hline personal and academic characteristics & $\mathrm{No}=174$ & $\%$ \\
\hline Age (years) & & \\
\hline$<20$ years & 31 & $\mathbf{1 7 . 8}$ \\
\hline$\geq 20$ years & 143 & 82.2 \\
\hline Min. - Max. & \multicolumn{2}{|c|}{$19.0-23.0$} \\
\hline Gender & & \\
\hline Male & 56 & 32.2 \\
\hline Female & 118 & 67.8 \\
\hline \multicolumn{3}{|l|}{ Current Academic Year } \\
\hline First & 32 & 18.4 \\
\hline Second & 41 & 23.6 \\
\hline Third & 45 & 25.9 \\
\hline Fourth & 56 & 32.2 \\
\hline \multicolumn{3}{|l|}{ Attending Training program } \\
\hline Not have courses & 152 & 87.4 \\
\hline Yes have courses & 22 & 12.6 \\
\hline
\end{tabular}

Table (2): Number and percent distribution of students according to their self-directed learning readiness score (n 174)

\begin{tabular}{||ll|l|l|}
\hline \# SDLR score & No= 174 & \% \\
\hline below average & $(58-201)$ & 72 & 41.4 \\
Average & $(202-226)$ & 47 & 27 \\
above average & $(227-290)$ & 55 & 31.6 \\
\hline
\end{tabular}

\# SDLR (self-directed learning readiness) 
Table ( 3): Mean score of self-directed learning readiness dimensions.

\begin{tabular}{|c|c|c|}
\hline \# SDLR Dimensions & $\begin{array}{c}\text { number of } \\
\text { item }\end{array}$ & mean \pm SD \\
\hline $\begin{array}{c}\text { self confidence in abilities and } \\
\text { skills for learning }\end{array}$ & 18 & $68.8 \pm 13.4$ \\
\hline Learning is a tool for life & 14 & $50.2 \pm 9.8$ \\
\hline Responsibility for own learning & 14 & $56.7 \pm 10.9$ \\
\hline Curiosity & 12 & $41.8 \pm 8.1$ \\
\hline \\
\# SDLR (self-directed learning readiness) \\
\hline
\end{tabular}

Table (4): Mean score of learning style as reported by students (n 174)

\begin{tabular}{|l|l|l|l||}
\hline Learning Style & No $=\mathbf{1 7 4}$ & $\mathbf{\%}$ & mean \pm SD \\
\hline Visual & 49 & 28.2 & $9.78 \pm 3.797$ \\
\hline Auditory & 47 & 27.0 & $9.14 \pm 3.9$ \\
\hline Kinesthetic & 78 & 44.8 & $11.07 \pm 4.693$ \\
\hline
\end{tabular}


Table (5:) Difference description of learning styles and self-directed learning readiness

\begin{tabular}{|c|c|c|c|c|c|c|c|c|c|c|}
\hline \multirow{3}{*}{ \# SDLR } & \multicolumn{6}{|c|}{ learning styles } & \multirow{2}{*}{\multicolumn{2}{|c|}{ Total }} & \multirow{3}{*}{$\mathbf{X}^{2}$} & \multirow{3}{*}{$\mathbf{P}$} \\
\hline & \multicolumn{2}{|l|}{ Visual } & \multicolumn{2}{|c|}{ Auditory } & \multicolumn{2}{|c|}{ Kinaesthetic } & & & & \\
\hline & $\mathbf{N}$ & $\%$ & $\mathbf{N}$ & $\%$ & $\mathbf{N}$ & $\%$ & $\mathbf{N}$ & $\%$ & & \\
\hline $\begin{array}{l}\text { First year (32) } \\
\text { Below average } \\
\text { Average } \\
\text { Above average }\end{array}$ & $\begin{array}{l}3 \\
2 \\
10\end{array}$ & $\begin{array}{l}9.4 \\
6.3 \\
31.3\end{array}$ & $\begin{array}{l}2 \\
2 \\
1\end{array}$ & $\begin{array}{l}6.3 \\
6.3 \\
3.13\end{array}$ & $\begin{array}{l}4 \\
1 \\
7\end{array}$ & $\begin{array}{l}12.5 \\
3.13 \\
21.88\end{array}$ & $\begin{array}{l}9 \\
5 \\
18\end{array}$ & $\begin{array}{l}28.13 \\
15.62 \\
56.25\end{array}$ & 0.337 & 0.492 \\
\hline Total of first year & 15 & 46.88 & 5 & 15.62 & 12 & 37.5 & 32 & 100 & & \\
\hline $\begin{array}{l}\text { Second level (41) } \\
\text { Below average } \\
\text { Average } \\
\text { Above average }\end{array}$ & $\begin{array}{l}12.195 \\
0 \\
4.88\end{array}$ & & $\begin{array}{l}3 \\
2 \\
2\end{array}$ & $\begin{array}{l}7.317 \\
4.88 \\
4.88\end{array}$ & $\begin{array}{l}8 \\
10 \\
9\end{array}$ & $\begin{array}{l}19.51 \\
24.39 \\
21.951\end{array}$ & $\begin{array}{l}16 \\
12 \\
13\end{array}$ & $\begin{array}{l}39.024 \\
29.27 \\
31.71\end{array}$ & 0.268 & 0.142 \\
\hline Total of second year & 7 & 17.073 & 7 & 17.073 & 27 & 65.85 & 41 & 100 & & \\
\hline $\begin{array}{l}\text { Third year (45) } \\
\text { Below average } \\
\text { Average } \\
\text { Above average }\end{array}$ & $\begin{array}{l}6 \\
2 \\
1\end{array}$ & $\begin{array}{l}13.33 \\
4.44 \\
2.22\end{array}$ & $\begin{array}{l}12 \\
5 \\
3\end{array}$ & $\begin{array}{l}26.66 \\
11.11 \\
6.66\end{array}$ & $\begin{array}{l}11 \\
4 \\
1\end{array}$ & $\begin{array}{l}24.44 \\
8.89 \\
2022\end{array}$ & $\begin{array}{l}29 \\
11 \\
5\end{array}$ & $\begin{array}{l}64.44 \\
24.44 \\
11.11\end{array}$ & 0.945 & 0.129 \\
\hline Total of third year & 9 & 20 & 20 & 44.44 & 16 & 35.56 & 45 & 100 & & \\
\hline $\begin{array}{l}\text { Forth year (56) } \\
\text { Below average } \\
\text { Average } \\
\text { Above average }\end{array}$ & $\begin{array}{l}4 \\
5 \\
7\end{array}$ & $\begin{array}{l}7.14 \\
8.93 \\
12.5\end{array}$ & $\begin{array}{l}7 \\
5 \\
1\end{array}$ & $\begin{array}{l}12.5 \\
8.93 \\
1.79\end{array}$ & $\begin{array}{l}7 \\
9 \\
11\end{array}$ & $\begin{array}{l}12.5 \\
16.07 \\
19.64\end{array}$ & $\begin{array}{l}18 \\
19 \\
19\end{array}$ & $\begin{array}{l}32.14 \\
33.93 \\
33.93\end{array}$ & 0.195 & 0.139 \\
\hline Total of forth year & 16 & & 13 & & 27 & & 56 & & & \\
\hline Overall total & 49 & 28.16 & 47 & 27.01 & 78 & 44.83 & 174 & 100 & 0.871 & 0.246 \\
\hline
\end{tabular}

*Significant at $\mathbf{P}<0.05$

\section{DISCUSSION:}

The aim of this study is study readiness for self-learning and learning style preferences among nursing students at Port-Said University. this study also investigated whether there were association between self-directed learning readiness and learning style preferences.

The first objective of the study was to assess the nursing student's readiness for selflearning at Port-Said University. The study findings showed that slightly more than two- 
fifths of studied nursing students' had low readiness for self- learning. This may be attributed to the transition from traditional education that students depended on teacher in secondary school. This finding is consistent with the study of Yuan, Williams, Fang and Pang (2012) who found that more than one third of Chinese baccalaureate nursing students rep0rted a low SDLR. Moreover, Lestari and Widjajakusumah (2009) in Indonesia indicated that only half of the students had low to moderate sc0res f0r selfdirected learning readiness.

In contrast a study by El-Gilany and Abusaad (2013) who reported that more than three quarters Of Saudi nursing students in Al Gouf university had high level of selfdirected learning. Similarly, Safavi, et al(2010) found that the majority of Jordanian and Iranian nursing students enjoyed a high level of SDLR.

The study demonstrates that the higher dimension among SDL readiness scale highest means score is self confidence in abilities and skills for learning.This contradicted with the results of Saleh, Sambawa, Bardawan and Naqali, (2016) who found that the highest dimension in the SDL readiness scale in the standard and normative deviation is responsibility for own learning in their study on medical students at Umm Al-Qura University, Saudi Arabia .

The second objective of the study was to identify the nursing students' learning style preferences at Port-Said University The second objective of the study is to identify the nursing students' learning style preferences at Port Said University. The present study findings displayed that the higher percentage of studied nursing students were prefer kinesthetic learning style. This may be attributed to students are most successful when they are engaged on activity rather than sitting for hours in a classroom.

The findings of the present study were consistent with what Vaishnav and Chirayu (2013) who found in their study on a sample of 200 students various schools at Nagpur City in Maharashtra in India that the majority of learners prefer kinaesthetic learning style. In addition to Peacock (2001) has examined the learning style preferences of students in the Department of English at the City University of Hong Kong. The results of his study show that students prefer kinaesthetic learning style.

However, this finding contradicted with the findings of Abidin, Rezaee, Abdullah and Singh (2011) who found out that kinesthetic learner were the least among students' in 
Malaysia in their studies that investigate the relationship between learning styles and overall academic achievement.

In the same line, Gilakjani (2012) find out that more than half of the students preferred visual learning style, more than one third of the students' preferred auditory learning style, and only lowest percent of the students preferred kinesthetic style, in his study about learning styles of the learners and teaching styles in Islamic Azad University of Lahijan in Iran.

The third objective of the study was finding-out the relation between nursing students' readiness for self-learning and their learning style preferences at Port-Said University. The present study findings showed that there is no significant relation between nursing students' readiness for self-learning and their preferred learning style.

The findings were consistent with what AbuAssi and Alkorashy (2016) who found that there was no statistically significant relation between nursing students' readiness for self-learning and their learning style preferences in their study am0ng nursing students at king Saud University. Similarly, El-Gilany and Abusaad (2013) in there study find out that the SDLR score does not affect learning style. As well this is in agreement with Iranian study conducted by Safavi et al., (2010), but is in contrary to Linares (1999) study in USA reported that SDLR appears to affect learning style (Linares, 1999)

Finally, the need for nursing students to be self-directed learning and to pursue knowledge and skills is critical aspect in their role is important for maintaining up to date. The opportunity to learn through self-direction already exists in undergraduate nursing students. This encourages college policymakers to implement the SDL policy.

\section{CONCLUSION:}

Based on the study findings concluded that two fifths of students had low readiness for self- learning at Port-Said University. Moreover, the most preferred learning style among studied nursing students was kinesthetic. As well, there is no statistically significant relation between self-directed learning and learning style. 


\section{RECOMMENDATIONS:}

The following recommendations were inferred from the study:

1. Students need support to move from traditional education to more active and independent education, relying on self-learning.

2. Students need to continuously assess opportunities for readiness for self-directed learning.

3. Faculty should develop strategies to promote SDLR. And Students' educators should assess and assist their students in identifying and learning through their own style preferences.

\section{REFERENCE:-}

Abidin, M. J. Z., Rezaee, A. A., Abdullah, H. N., \& Singh, K. K. B. (2011). Learning styles and overall academic achievement in a specific educational system. International Journal of Humanities and Social Science, 1(10), 143

AbuAssi, N. E., \& Alkorashy, H. A. E. (2016). Relationship between learning style and readiness for self-directed learning among nursing students at king Saud university, Saudi Arabia. International Journal of Advanced Nursing Studies, 5(2), 109-116.

Alharbi, H. A. (2018). Readiness for self-directed learning: How bridging and traditional nursing students differs? Nurse education today, 61, 231-234.

BillT, Rosie VAK Learning Styles. (2019). Retrieved from https://www.mindtools.com/pages/article/vak-learning-styles.htm

Chislett, V. Msc, and Chapman, A., 2005 From www.businessballs.com. VAK test questionnaire.

El-Gilany, A.-H., \& Abusaad, F. E. S. (2013). Self-directed learning readiness and learning styles among Saudi undergraduate nursing students. Nurse education today, 33(9), 1040-1044. 
Fein ML (2014) Redefining higher education: How self-direction can save colleges: Transaction Publishers.

Francis, D., Mahlomaholo, S., \& Nkoane, M. (2010). Praxis towards sustainable empowering learning environments in South Africa: AFRICAN SUN MeDIA.

Gerding, S. K. (2007). The accidental technology trainer: A guide for libraries. Medford, NJ: Information Today

Gilakjani, A. P. (2012). A match or mismatch between learning styles of the learners and teaching styles of the teachers. International Journal of Modern Education and Computer Science, 4(11), 51.

Guglielmino, L. M. (2013). The case for promoting self-directed learning in formal educational institutions. SA-eDUC, 10(2).

Hoban, J. D., Lawson, S. R., Mazmanian, P. E., Best, A. M., \& Seibel, H. R. (2005). The self-directed learning readiness scale: A factor analysis study. Medical Education, 39(4), 370-379.

https://www.mindtools.com/pages/article/vak-learning-styles.htm

Kan'an, A., \& Osman, K. (2015). The relationship between self-directed learning skills and science achievement among Qatari students. Creative Education, 6(08), 790

Lestari, E., \& Widjajakusumah, D. (2009). Students' self-directed learning readiness, perception toward student-centered learning and predisposition towards studentcentered behavior. South East Asian Journal of Medical Education, 3(1), 52-56

Linares AZ (1999), Learning styles of students and faculty in se-lected health care professions. [Comparative Study]. Journal of Nursing Education 38(9),

Moran, A. (1991). What can learning styles research learn from cognitive psychology? Educational Psychology, 11(3-4), 239-245.

Murad, M. H., Coto-Yglesias, F., Varkey, P., Prokop, L. J., \& Murad, A. L. (2010). The effectiveness of self-directed learning in health professions education: a systematic review. Medical education, 44(11), 1057-1068.(Murad et al., 2010) 
Örs, M. (2018). The Self-Directed Learning Readiness Level of the Undergraduate Students of Midwife and Nurse in Terms of Sustainability in Nursing and Midwifery Education. Sustainability, 10(10), 3574.

Peacock, M. (2001). Match or mismatch? Learning styles and teaching styles in EFL. International Journal of Applied Linguistics, 11(1), 1-20.

Prabjanee, D., \& Inthachot, M. (2013). Self-directed learning readiness of college students in Thailand. Journal of Educational Research and Innovation, 2(1),

Safavi, M., Shooshtari, S., Mahmoodi, M., \& Yarmohammadian, M. H. (2010). Selfdirected learning readiness and learning styles among nursing students of Isfahan University of Medical Sciences. Iranian Journal of Medical Education, 10(1), 2736.

Salih, M., Sembawa, H., Baradwan, S., \& Nuqali, A. (2016). Self-directed learning readiness among medical students at Umm Al-Qura University, Saudi Arabia: A cross sectional study. Sch Bull, 2(1), 20-6.

Siminica, M., \& Dumitru, A. (2013). Self-directed learning in economic education. International Journal of Education and Research, 1(12).

Vaishnav, R. S., \& Chirayu, K. (2013). Learning style and academic achievement of secondary school students. Voice of Research, 1(4), 1-4.

Yuan, H. B., Williams, B. A., Fang, J. B., \& Pang, D. (2012). Chinese baccalaureate nursing students' readiness for self-directed learning. Nurse education today, $32(4), 427-431$. 
العلاقة بين الاستعداد للتعلم الأتي وأسلوب التطلم المفضل بين طلاب التمريض

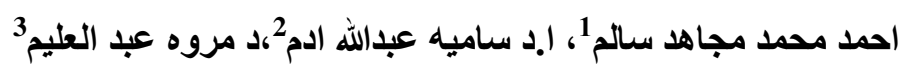

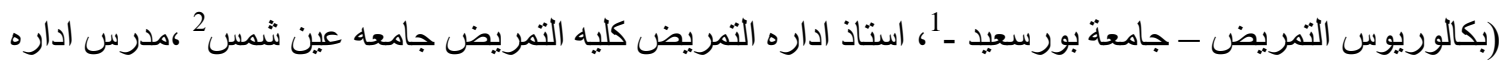

التمريض ،كليه التمريض جامعه بورسعيد3

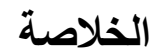

يعد التعلم الذاتي مهارة ضـرورية للطلاب ليظلا ا في تعلم مستمر مدى الحيـاة وليتمكن طلاب الجامعة مـن اكتساب المعرفة و النجاح أكاديمياً كما ينبغي تعزيز الوعي بأسـاليب التعلم لديهه. الهدف مـن الدراسـه: دراسـة العلاقة

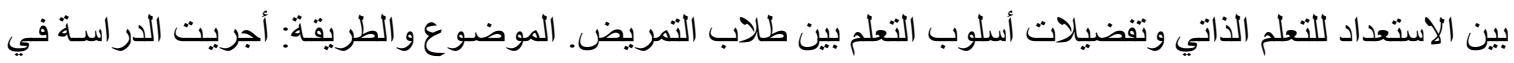
كلية التمريض / جامعة بورسعيد باستخدام تصميم بحثّي وصفي متر ابط. تم ضم 174 طالبَّا من السنو ات الأكاديميـة الأربعة في الدر اسة. تم استخدام أداتين هما: مقياسالاستعدادللتعلم الذاتي و استبيان التقييم الذاتي لأنماط التعلم ـ النتائج: حصل 27٪ من طلاب التمريض الذين تمت در استهم على درجـة متوسطة في الاستعداد للتعلم الموجه ذاتيًا ، بينما كان 41.4\% منهم متوسطًاو 31.6٪ أعلى من المتوسط. علاوة على ذلك ، كان أسلوب التعلم الأكثر تفضيلًا بين الطلاب هو الحركية (44.8\%) ، ثم البصري (28.2\%) و السمعي (27٪). الخلاصة: خلصت نتائج الدراسـة إلى عدم

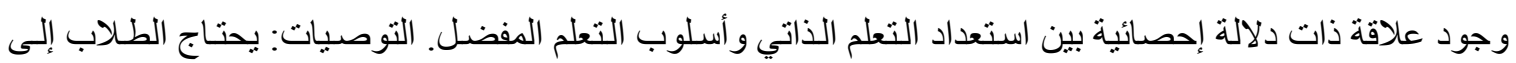
الدعم للانتقال من التعليم التقليدي إلى التعليم الأكثر نشاطًا واستقلالية و المعتمد على التعلم الذاني. الكلمات المرشده: التعلم الذاتي، أسلوب التعلم، طلاب التمريض 